\title{
ASPECTS OF STUDYING THE VERBAL LEVEL OF CATTLE-BREEDING RITUALS
}

\section{Liudmila Lobanova}

Research Fellow

Department of Folklore, Institute of Language, Literature, and History

Komi Science Centre, Russian Academy of Sciences, Russia

Email: sergejluda@mail.ru

\begin{abstract}
This article contains an analysis of a verbal component of cattlebreeding rituals. In terms of their genre, incantatory texts are divided into five different categories: sorcery, ritual dialogues, incantations, lamentations, and prayers, out of which the most widespread is sorcery. As a result of a structuralsemantic analysis of sorcery, two types of texts have been singled out. Sorcery with a closed structure consists of two parts, and its parts can be related as opposition or comparison. Sorcery with an open structure is divided with respect to its recipients: animals, saints, and the domovo $i^{1}$.
\end{abstract}

Keywords: incantations, Komi cattle-breeding tradition, lamentations, sorcery

\section{KOMI CATTLE-BREEDING TRADITION}

In the traditional Komi household, hunting and fishing were supplemented by cattle-breeding and agriculture, and the former was an essential prerequisite for the development of the latter: cattle were bred for manure, without which the scanty local soil was unsuitable for growing crops. In the conditions of the extreme north, where the indoor season makes up 7-8 months, cattle-breeding was a labour-intensive process, limited by the total surface area of grasslands and pastures. Traditionally, stock-rearing for the purposes of producing dairy products for personal consumption was very popular, while horses were bred for their draught power and as a means of transport, and sheep for their wool. For keeping cattle, special outbuildings were built (гид, шьь, карта, гидня 'cattle barn'), which were integrated into a residential compound: a warm one for cows and cold one for sheep and horses (see Fig. 1-4). Cattle grazed for 4-5 months, being pastured without any supervision, and in a number of traditions, cattle would be sent out to summer pastures. Until the 1930s, the livestock number in households, depending on the size of the family and the total surface area 
of grassland owned, amounted to 1-10 cows, 1-3 horses, and 3-15 sheep. After the introduction of collective property, the livestock population at individual farmsteads decreased. An increase in the livestock population of the cattle stock was observed in the $1990 \mathrm{~s}$, and in the recent decade there has been a sharp decline that is related to economic conditions and the agricultural situation in the country as a whole.
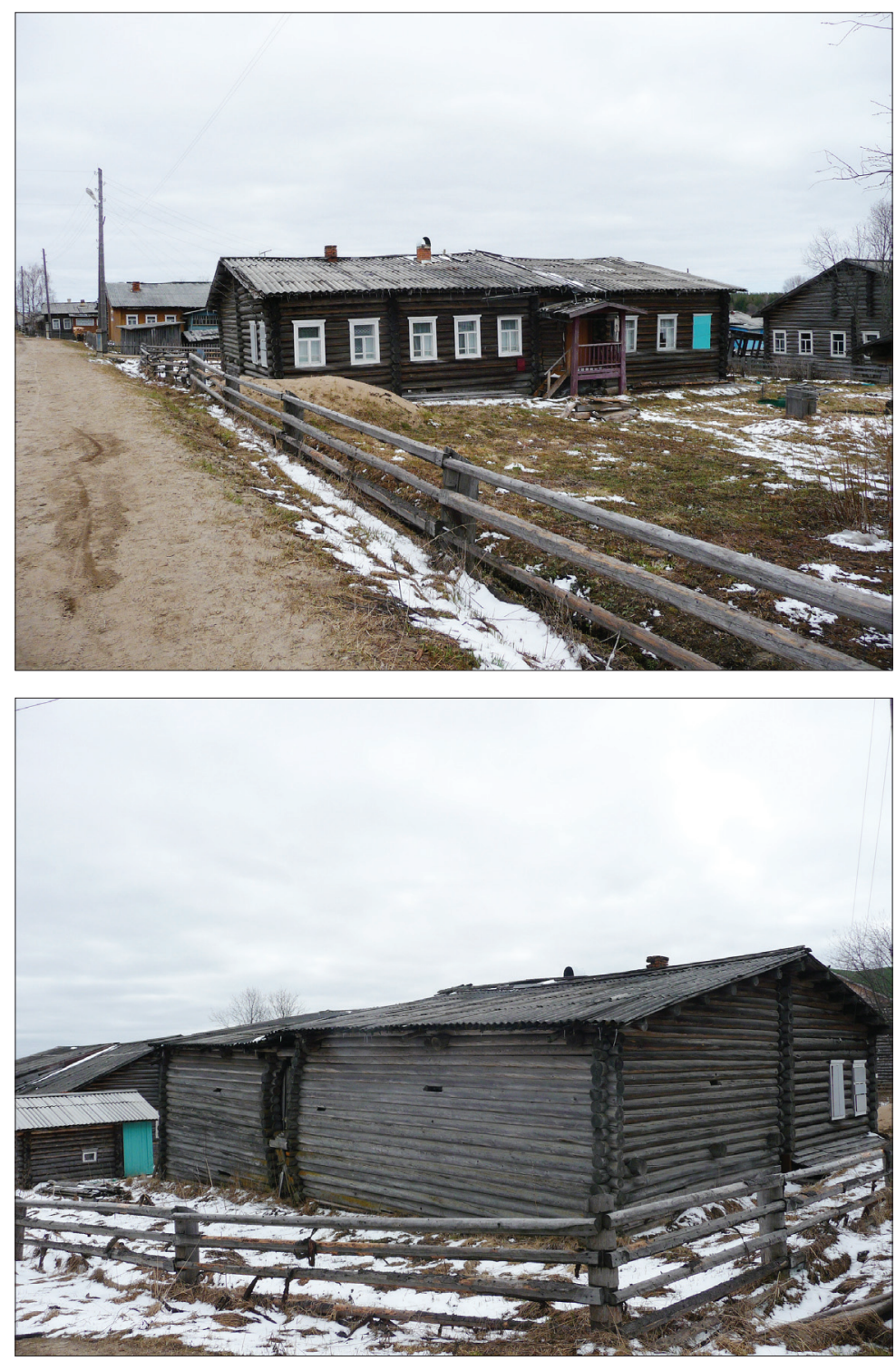

Figure 1-2. A particular type of house-yard in the south-eastern part of the Komi Republic (front and back views). Under one slope of the roof, there is the living space; under the other one, the utility space. On the lower level, there are cattle barns. Village of Nivshera, Kortkerossky District. Photograph by Liudmila Lobanova 2014. 

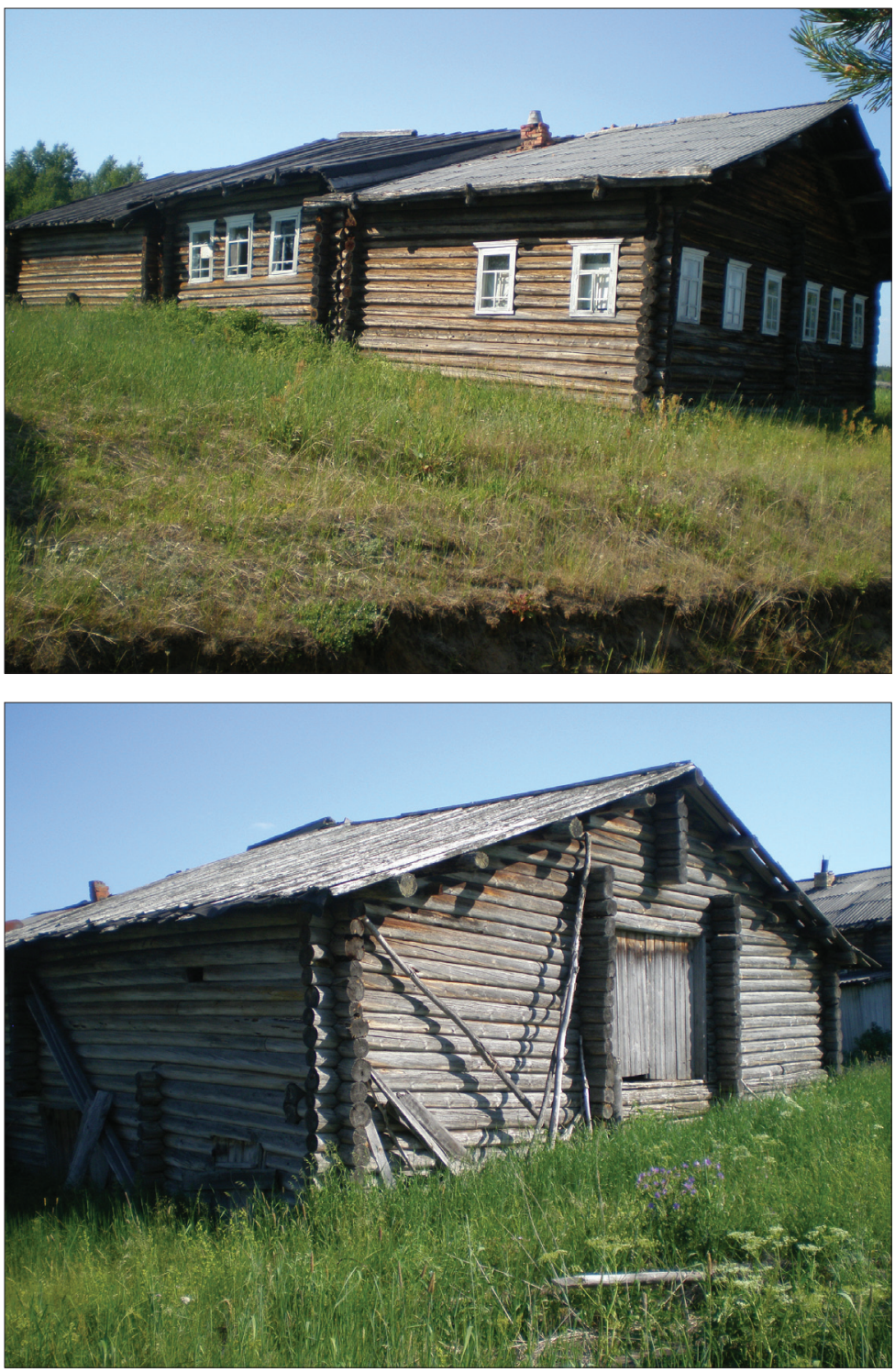

Figure 3-4. A particular type of house-yard in the western part of the Komi Republic (front and back view). The utility part is in the background; premises for cattle are on the lower level of the utility space and in the underground of the middle izba (cabin). In the background, there is a log ramp for carting hay. Village of Körttuvya, Udorsky District. Photograph by Liudmila Lobanova 2011.

In terms of spiritual culture, cattle-breeding was represented by a set of rituals, beliefs, legends, superstitions, prescriptions, bans, magical techniques, incantatory texts, etc., and on the whole, it is a ritualized activity. All of the actions pertaining to cattle management, even the most utilitarian and routine, can attain magical interpretation. 
Cattle-breeding as a branch of traditional activities requires the mastery of not only a number of practical skills related to cattle management, but also the acquiring of certain knowledge that is popularly referred to as cкӧт гӧгӧp möдӧ. 'knowledge about (literally 'around') cattle'. The mastering of such knowledge takes place after a change in social status, i.e., when a girl gets married, starts a family and a household, and becomes the mistress of the house. Most often the 'knowledge about cattle' (sometimes it is more specific, for instance, мӧс гӧгӧр тӧднь 'to know about (literally 'around') a cow' involves mastering protective, productive, and remedial magic, including completing some ritual actions and saying incantatory texts: ${ }^{2}$

Пӧрысьясыд ёна скӧттӧ видзлісны и меньлм тоже передайтэлась, и ме скӧтӧн же ола. Зэв унатор висьтавліснь, кор ме ичӧт на вӧлі, и зэв унатор кььвлі. Миян ьцжыл мамыс вӧлі шуӧ, ӧти женшина миян татӧн вӧлӧла мӧс

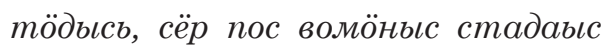
ставнас миянладорьсь вӧлі мунӧ нелямын кьлмын мӧс, и если кӧ пе ме ӧні кӧсъя, шува пе кутшелке кьь, и став мӧскьс пе татчи пласьт усяс, мыцйла пӧ мӧс гӧгӧрысс нинӧм оз тӧдны, некутшем молитва пӧ лӧскьсль абу льљделаэсь. Ме пӧ ӧні пӧрьцсь нин, да сійес ог нин вӧч. И вот, значит, лии, ӧнія йӧз, молитваяссэ лӧс гӧгӧрьс нинӧл ог тӧдӧй, сьє вӧсна верласньц тӧдьєсь да кужььсь йӧз лӧстӧ весиг висьлӧдны. ${ }^{3}$
Elderly people would keep lots of cattle, and they handed it over to me. I also breed cattle. They would say many different things when I was little. I heard many stories. My grandmother said that there had been a woman here who had magic knowledge of cows. Once when a herd of cattle, about forty cows, was crossing the bridge, she said that if she wanted she could say a word that would make the cows lie down flat, because [their owners] did not know anything about the cows, they had not said any prayers. But then she added that she was too old for that and would not do so. It means that we, the people of the present, do not know any prayers for our cattle, and those who know them and are able to use them can call illnesses upon the cattle.

The lack of such knowledge, an unusual or a more serious case, can lead to the need for turning to the sorcerer for help, whose knowledge, among other things, is determined by knowing incantatory words, i.e., нuлкь८ ${ }^{4}$, which is also reflected in the name of such people, i.e., нилкьв видзысь, ныллкьвьл, нилкыє кутьль 'incantation keeper', who are ascribed with the abilities both to treat animals and to bedevil them. 
(Висьтавлісны, мыьй Саввӧыс (They said that Savva could bedevil тшыкӧдлӧла мортӧс ли скӧтӧс?) a person or cattle?) Yes, they say Но так сія пӧ ёна тшыкӧдчылӧла. he bedevilled many people. He was Ciя ачьı пӧ ошйьсьӧл. Me nӧ boasting about that. He said that he асьлнас пӧ чечча, кьлльӥ вылӥ would wake up in the morning and nе пета, нилкылсӧ пӧ лэдза, go out to the front porch, and send an и тӧлнас пӧ кьччи нуӧ (а сэн Кось incantation, and the wind would blow саяс яг, Вайлиос яг, сэн Вайлӧс-ю, it away (there is a forest behind the но и Вайлӧс ягӧн шуӧнь, сэсся village of Kos, the Vaimös Forest, there пӧ меял нилкылйьс), тӧлнас is the Vaimös River, and the forest нилкьлсӧ тӧлзьӧдо̆, кутшиол пуӧ is also called Vaimös), and the wind веськалӧ, сія пуыс косьлй. Сія пӧ would take the incantation into the ошйысьӧ, Косьватас пӧ Лихачевка forest, and if it hit a tree, it dried out. ватасыс, став пӧ леял поньсь кос He was boasting that all of the people пессӧ сотӧ, кос кондасӧ, сія пӧ nуыс living in the vicinity of Likhachevka косьлӧ, сія сэсся пес вылӧ ваялӧны, were burning dry wood and deadwood менал понысь пӧ ставыс Лихачевка because of him, because the trees were ватасыс пессӧ сотӧны. ${ }^{5}$

drying out, and then they would cut them into firewood. He said that all of the inhabitants of Likhachevka were heating up their houses with his firewood.

\section{SPECIFICATIONS OF SOURCES}

This research is mainly based on field materials, recorded in the form of interviews with the carriers of the tradition on different topics related to the cattlebreeding tradition (cattle maintenance and management). In terms of content, the records are not observations of actual rituals (recording the ritual practice at the moment of its actualization), but oral descriptions of rituals (what people usually do when they let the cattle out to pasture), specific anecdotal evidence (how they treated a cow with a swollen udder, or how they brought a cow which had just been bought into a cowshed), memories, stories, edifications, etc. ${ }^{6}$ Without any doubt, a perfect option would have been observing a ritual and recording it at the moment of its actualization, but under the conditions of folkloric-ethnographic fieldwork, researchers rarely have a chance to witness and record actual ritual practice. 
Material of this kind was also found in archival manuscripts, ${ }^{7}$ in published linguistic and folkloric material (see Uotila 2006; Rédei 1978), and in research concerning the studies of magical representations and incantatory texts (see Vetoshkina 1982; Kudryashova 1991; Sidorov 1997 [1928]). In addition to that, a considerable part of the material is represented in the form of incantatory texts, selected from the handwritten notebooks of informants.

When the material is recorded this way, it is impossible to differentiate between cattle-breeding rituals using the principle of existence or absence of the verbal level and study the variation of texts. At the same time, this format allows to analyse the context of the existence of incantatory texts and popular perceptions of the role played by a word.

\section{THE PROBLEM OF DISTINGUISHING THE VERBAL COMPONENT}

The majority of the material was recorded in the form of interviews, in which informants spoke about a ritual and described actions and events, while the verbal component would recede into the background. This was furthered by the type of a speech act itself as well as by the questions asked by the collector: What would you do if a cow did not give milk? How did you let cattle to pasture for the first time? This is why quite often additional questions had to be asked about the verbal component of a ritual.

(Кьљзи лӧстӧ лудад ледводдзаьсь лэдзан?) Сійес вот лӧстэ лэдзан, наприлер, тульснас лэдзан первой после зиль, значит, миян сійе тоже, ог тӧд, коді висьталіс бабйес ли, сиктсаясыс ли, тоже менал прилета. Кор лиоскыс петэ, бӧрбя коктуйяссэ ме гидйас бӧр шыбита, мед тӧдны горт мӧдас. Сійа муас коле коктуйьс, и сійе мусэ, мед и куйедас шагнитас, куйедсэ сійес гидйас бӧр шыљита. (Мыци шувад?) Кьљзи коктуйьљ сэн олэ, сідз же мед вӧлілоктэла татче. Ас кьвъеснад, вед дзик же сідз, ас кьвъесэн cоставитэла. ${ }^{8}$
(How do you let a cow to pasture for the first time?) When you let a cow to pasture for the first time, after winter, in spring, well, I don't know who told me about that, grannies or home folk, but there is a superstition. When a cow leaves the cowshed, I throw the last mark of a trail back into the cowshed, so that it will know where its house is. Because this mark of a trail is in the soil, or in manure, and I throw that manure back into the cowshed. (What do you say when you do that?) Your trail goes to the cowshed, and you should come back to the cowshed. I say it in my own words, because I always say it in my own words. 
Вербасӧ ваян, а Ёгорей луннас нин You bring pussy willow in, and on сійӧс [скӧтсӧ] лэдзӧны видз выллӧ, George's Day they let them [the catи сійӧн сійӧс швачӧдӧны вербанас. tle] out into the pasture, and they whip (Мьцикӧ шуалӧньє) а "Ёгор- them with pussy willow. (What do they батюшко, скӧтӧс видз-хранит” - say?) 'Father George, save and protect тадзи, а ме сэсся ог тӧд. ${ }^{9}$ the cattle', something like that, I don't know anything else.

In the majority of cases, incantatory texts would be perfectly incorporated into the stories of informants and described along with the actions. It was introduced with the help of a speech verb in direct or indirect speech, pointing at the synchronism of a word and action, and also less frequently at their sequence. For instance:

Ветльь лися кладбищео̆, боссь Go to the cemetery and take a chip, кладбищесьыс щепка, пу щепка. a wooden chip. When you come back, Локтан да мьиикӧ гид белляс вӧч make a hole in the cowshed door post, розь, да щепкасӧ сэтчӧ, шуан: [hammer] the chip into the hole and "Кьљз тая щепкасӧ тувъялі да оз say: 'I have hammered the chip into вӧрзьь, сідзжӧ мӧскьсльсь меял the hole, and no one will touch it, and мед нелтор оз ворзьӧд. '10 nothing will happen to my cow.'

(А мӧскьдлӧн кутшӧм праздникысе) Ог тӧд. А вӧӧ тай, шуасны, тувсов Ёгорей лун, шестое маянад. Ciйе пе вӧвлӧн праздник, вӧвьясэс йиреднь лэдзласны. Тошнад пе, Егорей-батюшко, йиред вӧӧястэ. Егорейыс ли мый ли йиредэ ли мыцй ли. Сідз тай вӧлі шуласньь. (Вӧвтэ лэдзиген шувасньь?) Да. ${ }^{11}$

(What festival do cows have?) I don't know. They said that the horses' day was George's Day in spring, on the sixth of May. It was a day when horses were let out to pasture. Father George, feed horses with your beard. George was supposed to feed them. This is what they said. (Did they say that while letting the horses out?) Yes.

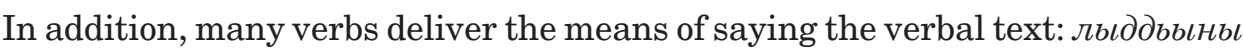
'to read, reread, enumerate', горӧдчьньь, горзыныь, горзыштавны 'to call out, to shout', шӧпкӧдны 'to whisper'. For instance:

"Гортӧ локтӧ, тайтӧ, лок, тайтӧ- 'Come home, cows, come home! Do not тайтӧ. Лёкъясль эн сетчӧ, некодль succumb to bad people, do not succumb эн сетчь. Кӧинбяс, лёк йӧз лед тэд to anyone. Let wolves and evil people оз мешайтны. Места тӧд, места not disturb you. Know your place, тӧд!” Тадзи горзіснь Ыджьљ know your place!' They used to shout Четвергад пач трубаад. ${ }^{12}$ it into a chimney on Holy Thursday. 
In the stories of some performers different nominative names also surface, such as кьєвъяс 'words', нилкьв 'invocation', прилета 'superstition', загӧвӧр 'incantation', молитва 'prayer', which are used as synonyms for designating an incantatory text. Additionally, incantatory texts can be named by the targeted object, for example, висьӧльсь 'from a disease', тшькӧдӧлььсь 'from blight', волидзысь 'from the evil eye', eliminating or getting rid of what the text is aimed at. In this case such names as cкömbıcb 'for (literally 'from') the cattle', лӧскысь 'for (literally 'from') a соw', лӥс локтӧлысь 'for (literally 'from') the cow coming back', which come up in the analogies listed above, on the basis of a ready-made language form, are of particular interest, and informants do not ponder on their meaning:

“Святые священнолученики, Власия, молите бога о нас”. Тайӧ скӧтысь молитва. Скӧтыд мыйке лоэ, да тайе лолитчены. ${ }^{13}$

'Holy martyrs, Vlasia, pray to God for us.' This is a prayer for (literally 'from') the cattle. They pray this way so that nothing bad would happen to the cattle.

Quite often incantatory texts are named after a Christian saint who is the addressee of the prayer, and also by the first word or the main motif of the text, which primarily helps to keep the text in the memory of the performer. For instance:

(Кор первойьıсь скӧттӧ лудӧ лэдзан, мый вӧчан?) Но кутшӧлкӧ лолитва льљдян “Вӧскреснӧй лолитва”, сэсся Ёгорей, шестое, сэн кутшӧлкӧ молитва выйылм да, выйыл, выйылм, дул выллӧ оз усь, сразу дул вылӧ оз усь. Егорейьслӧн на выцйылм кутшӧлкӧ молитва ... "Христос c тобой Егорий храбрый, прили мою животину на всё полное лето u cnacu ux!'14

Сэки кресталэны ӧдзестэ, водзджык идрасясны, и кресталэны вӧлэл зӧлӧтэй толанэн пе. "Кристос печать, йигно-толно зӧлӧтӧй толаннад, зӧлӧтэй ключнад." Карта ӧдзестэ тадзи кресталэны да шувалэны. ${ }^{16}$
(What do they do when they let the cattle out to pasture for the first time?) Then you should say some kind of prayer, for instance, a Sunday prayer ${ }^{15}$, then George, on the sixth, there is also a prayer of some kind, there definitely is, but I can't think of it right now. There is another prayer addressing George: [what follows is the text of the original prayer] ... 'Let Christ be with you, you brave George, take my cattle for the whole summer and protect them!'

Then they would criss-cross doors, handle the cattle and criss-cross the cattle with a 'golden lock', like 'Christ's seal, close it down with a golden lock, a golden key'. This is what they say while criss-crossing the doors of the cowshed. 


\section{GENRE VARIETIES}

Incantatory texts that function within cattle-breeding rituals can be divided into five categories: sorcery, ritual dialogues, incantations, lamentations, and prayers. In terms of the latter, I mean canonical prayers that are said within cattle-breeding rituals (see the text cited above as an example). I will discuss them in detail below.

The main problem consists in distinguishing between sorcery and incantations, since the same texts are referred to as sorcery in one group of studies and as incantations in another. In Russian folklore studies, the trend is the following. If an incantation is used in the meaning of an 'incantatory text' and means a verbal means of magical impact, sorcery is not distinguished. When distinguishing between incantations and sorcery, a number of attributes that specify them as oppositions are used as a basis: dimensional texts with a complex structure and a carefully structured composition vs. short verbal statements; incantations prevail over action vs. sorceries are secondary, producible, dependent on the action; belong to the professional environment, arcane knowledge, sacral persons vs. common household knowledge; a part of a special ritual vs. being a part of practical ritual actions. However, when turning to some specific folklore material, categories become blurred, some transitional forms appear, and researchers tend to use one common term, which is 'incantations' (Fedosova 2007). In the current article, sorcery and incantations are regarded not as oppositions, but as different forms and means of verbal and magical impact, which can be singled out on the basis of the material related to the Komi cattle-breeding tradition. But we should specify right away that the list of genre variations provided above does not include all possible variations, since there are texts with unidentified particular genre characteristics (when the text is divorced from some ritual context) as well as transitional and contaminated forms.

\section{Sorcery}

The largest part of recorded texts are defined as sorcery, i.e., short verbal formulas that accompany various practical activities aimed at keeping and managing cattle (shearing sheep, milking cows, letting the cattle to pasture, etc.), communicating the ritual and magical function to the utilitarian practice, or being a part of a special ritual which accomplishes a producing and apotropaic function (cows are whipped with pussy willow branches for good health; milk is criss-crossed to protect it from bewitchment, etc.). 
First of all, there is sorcery expressed in interjections. They are included in a category of imperative interjections (will expressions) and used for calling an animal to behave in a certain way or stop doing something. In some cases, vocative interjections, which are used to call or drive animals away, are distinguished into a separate group (Popova 2000: 522).

Тӧлӧ (dial. тӧлэ) (SSKZD 1961: 375) is a call to a cow while milking it, which expresses the order to stop moving and stand still. The etymology of the word is unclear, and it might originate from the word ӧлӧднь 'to stop, calm down'.

Taŭmö (dial. maŭmə, mamьö) is a call to the cow, addressing the cow (SSKZD 1961: 363), mainly used to call the cows to come back home from the pasture, and this is what cattle owners say while driving cows into a shed. The etymology is unclear: there might be a relation to adverbs, pronouns, and particles with emphatic-intensifying and demonstrative semantics: maüö 'this one', mamчӥ 'over here', maŭ 'right here'. ${ }^{17}$

Вала-вала is an exclamation used to call cows to a watering place (Zhilina 1975: 161).

Tnpy is an exclamation used to stop a horse while driving it, or they would shout it trying to calm the horse down, while approaching or examining it.

Öcbm-öcbm (dial. möcb-möcb, öcbmö-öcbmö, öcbma-öcbma) is an exclamation used to call sheep (SSKZD 1961: 267). The etymology is unclear. In modern speech in similar cases the particle баль-баль is most commonly used; it is a derivative from бале 'a lamb'.

Calves and bull-calves are called with mnрутьӧ-тпрутьӧ (dial. mnрутиmпрути, тnруте-тпруте, пруть-пруть) and конь-конь (dial. коне-коне). In the last adaptation, at the suggestion of linguists, the common Permic stem *kon' 'a calf' is preserved (Lytkin \& Gulyaev 1999 [1970]: 133). Foals are called with an exclamation чиб-чиб (dial. чибӧ-чибӧ, чибе-чибе) (SSKZD 1961: 410), which is a derivative from a word чибӧ 'a foal'. Some of the interjections come across in the form of addresses in incantatory texts and will be described below.

Sorcery mainly consists of a single statement and is structured according to the model of directives, using imperative verb forms. On the basis of modern material, the overview of which is provided above, no specific popular name for such statements can be singled out. In earlier records of this kind, verbal and ritual actions were referred to as вордчьнь: 
Сәсся вӧлі ьюж шыриген вордчень. They would foretell while shearing Ыжюе шыраснь да вурунсэ бось- sheep. They would shear a sheep, take таснь киас да шуалэны, зыралэнь с wool in their hands and say things, rub миьш вывсэ и былэн да шуэны: it on the sheep's back and say:

Кӧчен мун,

Сюзен лок.

Кӧин кулальи ин шедэдчь, Go away as a rabbit, Come back as an owl.

Потшыс коласэ юртэ ин сюй, Ассььљ кӧзяин-кӧзяйкатэ тӧд, Гортэ волььвль. ${ }^{18}$

Don't get caught by a wolf,

Don't stick your head between thin poles, Know your master, Come back home.

The verb ворднь in the Komi language often comes across as a dialectal adaptation of the verbs синь 'wish, predetermine', and тунавны 'predict, foretell' (SSKZD 1961: 60, 337, 381), and it can also be used in the meaning 'to charm, to tell one's fortune'. Unlike dialectal adaptations, etymologically this verb originates from the word вор 'faculty of speech' (Lytkin \& Gulyaev 1999 [1970]: 63), which is why вордчьциь can be translated as 'to foretell'. In spite of the fact that this function is not expressed in modern recordings, it sticks to similar verbal-magical acts. Their purpose is to speak out the desired course of events, the expected outcome. These texts are accompanied by a number of certain actions of practical or magical nature, which is why we define them as sorcery.

In spite of a large diversity of sorcery, two structural types can be singled out. At the basis of sorcery with a closed structure ${ }^{19}$ (self-contained phrasal utterances - Grigory Permyakov (1988: 95); incantatory formulas - Valentina Kharitonova (1992: 3-37)) lie clichés consisting of two parts that can be related in the following way:

- Oppositions: 'Go away as a rabbit, come back as an owl', in which predicates (go away - come) and objects (rabbit - owl) are in opposition, whereas rabbit and owl are in opposition on the grounds of their level of fluffiness ${ }^{20}$ : a rabbit has short and thin fur, while the feathers of an owl are long and thick. Also, for example, the sorcery of Бӧр туйсэ вунэд, водз туйсэ вӧт ${ }^{21}$ 'Forget the road back, think of the road ahead', which is said when driving a cow that has just been bought into a cowshed. These statements are metaphorical. - Comparisons, in which the first part of the text (how..., where...) describes the original ritual situation and actualizes the required attribute, and in the second part, the desired situation is simulated:

Кьљз тая щепкасӧ тувъялі да оз вӧрзьь, сідзжӧ мӧскысльсь меял мед нелтор оз ворзьӧд. ${ }^{22}$

[I] have hammered the chip into the hole, and nothing will happen to my cow. 
Кьљзи тая саис лэбзяс да ьылла воше, мед менал вӧл вылісь тадзи же лэбзяс волидзис!

Just like this ash is scattered and disappears into thin air, let the evil eye be removed from my horse (Uotila 2006: 312).

Матёнка Туся, кӧн тэнад бурсиьљ да бӧжьљ, сэтӧн мед тэнад войсӧ телӧьд. ${ }^{23}$

Matyonka Tusya (literally 'a little berry'), where your mane and tail are, that is where your body [will be] at night.

The sorcery that was performed in the form of ritual motivations has also been included in this group.

Трӧича рос тоже вӧлэл пьртэнь Тree branches picked at Pentecost керкаэ ен доре, лӧсъястэ на were taken back home and put near вачкылэны, лед пе трӧича рос кодь the icons, and cows were whipped with здоровеесь лоанныц. ${ }^{24}$ them so that they would be as healthy and vigorous as Pentecost tree branches.

Мед берба-баля кодь здоровейесь So that you would be as healthy as мед, зӧлӧтаяс, лованньљ.. ${ }^{25}$ pussy willow catkins, my darlings.

Another type is the sorcery with an open structure (non-self-contained phrasal utterances in Permyakov 1988). The sorcery of this kind can be grouped according to addressees. In the first group of sorcery, the addressees are animals. Below you can see some examples of sorcery from different sources said while shearing sheep, which show the open-type structure of such texts, i.e., from short paroemia to the statements that contain addressees and enumerations:

Ыэлль тотшкӧны юрас шыригас: “Шьцран кад тӧд."

Кӧзяйкаяс, кор шырӧны ью, то сэк шуалӧны: "Ӧсьт-ӧсьт / шыран кад тӧд / кӧйинльь эн сетчьь / кӧрт потшӧс волӧн звирк четчышт / гоз баля вай. '27

Ыэж шыриген: “Ӧсьт-ӧсьт / шыранкад тӧд / Ёма-бабалі эн сеччи / бӧр гортэ лок / эн сечи!'”8
A sheep is tapped on its head while being sheared: 'Know the right time for shearing.'

When shearing sheep, women would say: 'Sheep, sheep, know the right time for shearing, don't get caught by a wolf, jump over the iron fence, give birth to a couple of lambs.'

When shearing sheep: 'Sheep, sheep, know the right time for shearing, don't get caught by Baba Yaga, come back home, don't get caught.' 
(Шыцигас нинэм оз вӧлі шуавнье?) A вед нинэл, шыригас только шыран воропен колскебта, Агниес тшӧкта же "Шыран кад тӧд / кӧрт потшысэд чеччышт / лёк Ёмальь эн сетчи.'

Шырнызаводитігас юрас таркедэнь шыраннас. "Пась кодь яя / сюръя кодь нэла / кӧртэн-пуртэн вийтэг / эн кув. 'эо
(Weren't they saying anything while shearing?) Nothing, I just tap their heads with the handle of the scissors after I have finished, and I make Agnia [daughter] do that, too: 'Know the right time for shearing, jump over the iron fence, don't get caught by Baba Yaga.'

At the beginning of shearing, they tap [a sheep] on the head with scissors. 'Be as furry as a fur coat, as long-lived as a column, don't be butchered with ironknife, don't die.'

The sorcery cited above, which was performed while shearing sheep, communicates the model of animal behaviour, on the basis of which the practical meaning of the ritual can be singled out, i.e., to keep the animal alive until the next shearing ('know the right time for shearing', 'jump over the iron fence / the hedge with seven stack stands', 'don't get caught by Baba Yoma'31, 'don't get stuck between thin poles', 'don't get caught by a dog', 'be as long-lived as a column', 'don't be butchered with an iron knife', 'don't die'), to improve its functional characteristics, in particular, its woolliness ('know the right time for shearing', 'bring good wool to your master'), and fertility ('give birth to a couple of lambs').

A peculiar feature of sorcery performed on animals is the match of the addressee and the recipient. It can be noticed that in the majority of cases, both the addressee and the recipient are omitted at the verbal level, but an emphasis is placed on them through the action that either precedes or accompanies the text. In our examples, a sheep is tapped on its head with scissors. And only two texts contain the exclamation öcbm-öcbm, used to call sheep. At the same time, the sorcery that accompanies ritual actions connected with cows was always marked by the name and colour of the animal with such additions as матушка, матёнка 'mother', рабича божья 'servant of God', which represent a respectful attitude to the cow and its position in the household, on the one hand, and ritual speech, on the other hand:

Бласлӧ Кристос, Лунашка-матушка, давай эн сетчы скӧтльь, этӧ лёк йӧз вылио, эн веськав, лючки. ${ }^{32}$

Bless us, Christ, mother Lunashka (literally 'Day, Little Day'), don't get caught by an animal, don't get caught by bad people, [let things come] right. 
The addressees of other kinds of sorcery are the Christian saints George, Blaise, Haralampus, Modest, Anastasia, Florus, and Laurus, who act as protectors and guardians of cattle and cattle-breeding in popular perceptions, and are sometimes referred to as the 'cattle gods', while their commemorative days are called вӧв праздник 'horse day', вӧв ниллун 'horse name day', лиосль лолебен $л у н$ 'cow prayer service day', etc. Sorcery of this kind can contain the following elements: an address, the kernel form, a recipient, and enumerations.

Ёгор-батюшко, скӧтӧс видз-хранит. ${ }^{33}$

Father George, save and protect my cattle.

Святы Ласей, святы Настасья, святы Модес, святы Харлалпия! Видзей да бережитэй ленсьылм Милка-матушкаэс став лёксьыс,

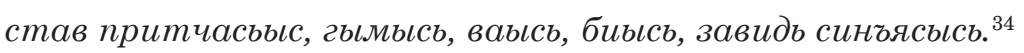

Saint Blaise, Saint Anastasia, Saint Modest, Saint Haralampus! Save and protect our mother Milka from anything bad, from any kind of evil, disaster, thunder, water, fire, or evil eye.

Господи благослови, святый Уласей! Сохрани и бережи от всяких хишных зверей и от зльх людей.

Bless me, oh, Lord! Oh, Saint Blaise! Protect the cattle from wild animals and evil people. ${ }^{35}$

Визюк ли Серед матушкаль, Господе, сет здоровье, избавит лёк йӧзысь, лёкьсь-притчась, ьљжжыд милӧстьнад. ${ }^{36}$

Vizyuk or Sered (literally 'Spotty, Black and White'), oh, Lord, bless the mother, save her from evil people, from bad and evil, at your greatest mercy.

The addressee of the third group of sorcery is the mythological character of the domovoi. In the popular view, the domovoi takes care of the well-being and fertility of the inhabitants of the cowshed, but it can also do damage to cattle if norms or rules are violated. As a rule, sorcery connected with the domovoi is performed with the following rituals:

- Moving to a new cowshed:

Дӧлӧвӧйӧ-двӧрӧлейо̆, батюшкаӧ-латушкаӧ, корлиличаӧ-лаленькаӧ, кудз ассььныд дитяясныдтӧ любитаныд да жалейтаныд, сідз жӧ и мисььнылм пар скӧтинанылиӧс любитӧ и жалейтӧ, пӧитӧ и кӧрлитӧ. ${ }^{37}$

Dömövöi, dvörölei, father and mother, foster mother, just as you love and pity your own children, please love and pity our cattle, give them food and drink. 
- Bringing home an animal that has just been bought or a new-born animal:

Дедушко-батюшко, дедушко-матушко! Я тебе гостинииь принёс. Мою скотину корли, пои да на мясо глади, да приголубь и шерсть очищай.

Grandfather-father, grandfather-mother! I have brought you some gifts. Give my cow food and drink, caress it and clean its fur. ${ }^{38}$

It should be pointed out here that sorcery addressing the domovoi was recorded in the Komi Priluzsky and Udorsky traditions, which are marked by close contacts with the Russian population of Kirov Oblast and Arkhangelsk Oblast.

The texts of sorcery are distinguished from ordinary speech and speech acts in terms of the ritual character of situations and the existence of rhyme, rhythm, and repetitions (Славнӧй Ёгорей, благӧславнӧй Ёгорей, сохранибережи 'great George, blessed George, save and protect us'), enumerations (любитӧ и жалейтӧ, пӧитӧ и кӧрлитӧ 'love and pity, give food and drink'), diminutive forms (дедушко-батюшко, корлиличаӧ-маленькаӧ 'grandfatherfather, foster mother'), and metaphors in texts.

\section{Incantations}

Incantations have a complex structure and composition and consist of several statements that are said in the course of a specific ritual situation. The semantics of the majority of incantations can be determined as rehabilitating, since they are aimed at improving and restoring the normal condition of domestic animals and are said in order to 'cure a sick animal', 'to bring back home a cow that spends a night in an unfamiliar place', etc.

The texts of incantations were recorded in contact areas that are representative of both the Priluzsky and Udorsky traditions, and in their linguistics and imagery they are close to the northern Russian tradition. Mainly these texts can be found in handwritten notebooks of informants alongside couplets, songs, and canonical prayers, which on the whole allows these notes to be designated as reminders in order to remember something. Some informants pointed out that they were repeating texts from the words of their mother or another woman who had good knowledge 'about cattle'. Besides, in their recorded form, the texts could also be passed over by the carriers of that knowledge. Whenever appropriate, incantatory texts were re-read, reconstructed from memory, or learned by heart. Let us have a closer look at several examples. 
Мӧс локтӧльссь.

Во иля отиа - 3 раза

На правой руке каленнӧй стена

На левой руке железного стьна на переде высокӧй гӧра

раба божия Серук мӧс

моз верль мунны

чужӧй пӧскӧтинаӧ.

чужӧй картаё. ${ }^{39}$

чужсой кӧзяйкалӧн. ${ }^{40}$

Старӧй кӧзяйкалӧн сёян-юанысс твёрдӧй калень да льс.

Выль кӧзяйкалӧн сёян-юаныс свежӧй трава да мягкӧй хлеб.
For (literally 'from') bringing back the cow.

In the name of the Father - [repeated] 3 times

A stone wall on the right hand, An iron fence on the left hand, A high mountain ahead.

The Lord's servant cow Syeruk, Let it not go far away, To somebody else's pasture, To somebody else's yard.

To another master.

The old master has food and drink, A hard stone and pine needles. The new master has food and drink, Fresh grass and soft bread.

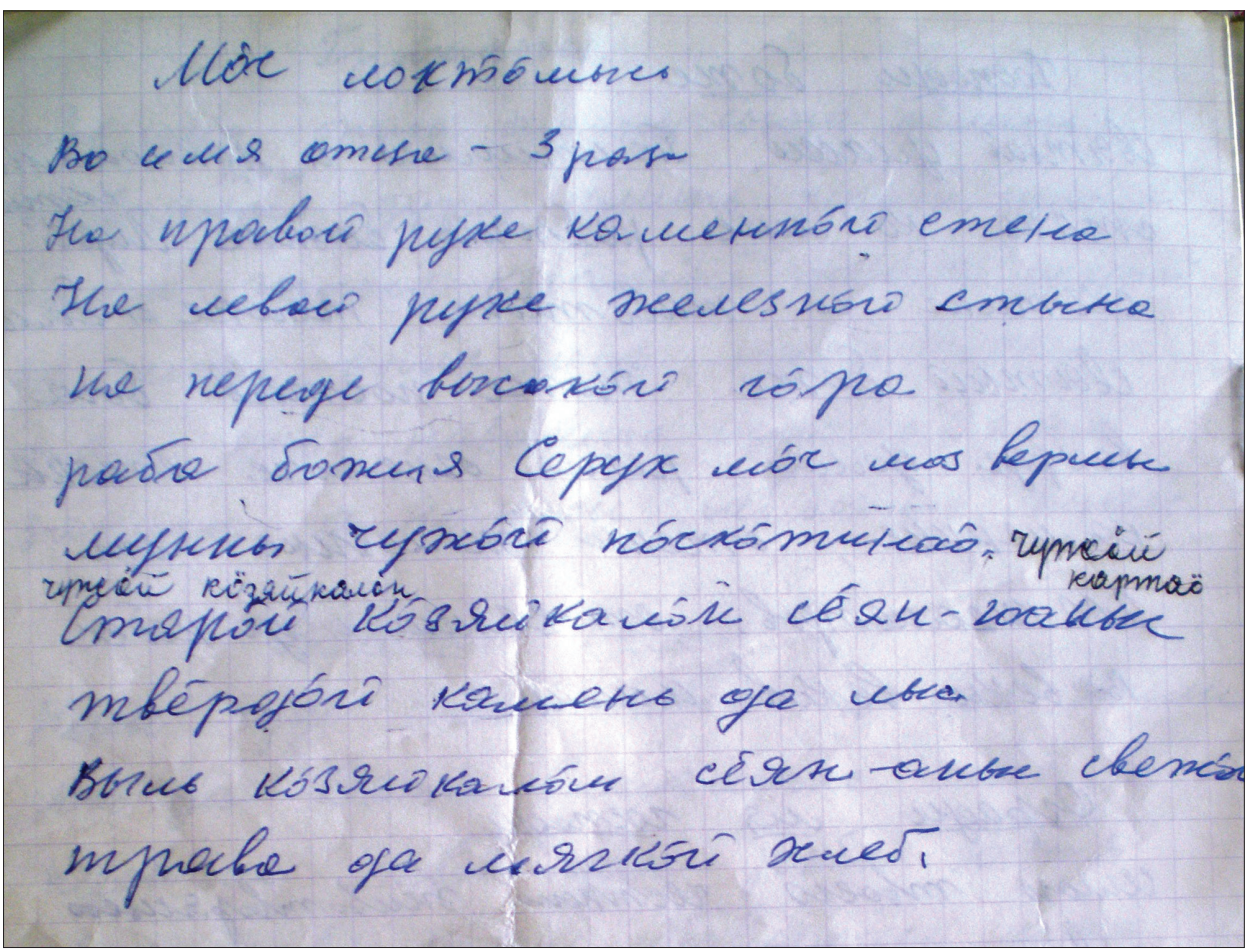

Figure 5. An incantatory text in the handwritten notebook of Nina Matveeva, born in 1931 (FFA: 28_06_78-79). Village of Yortom, Udorsky District. Photograph by Liudmila Lobanova 2011. 
The following structural parts can be distinguished in the text:

- Exposition, which was not recorded in full but can be reconstructed as in the name of the Father and the Son and the Holy Spirit', is repeated three times;

- Narrative part: “На правой руке каменнӧй стена / на левой руке железного стьна / на переде высокӧй гӧра."

- Incantatory part: “Раба божия Серук мӧс / моз верль мунны / чужӧй пӧскӧтинаӧ / чужӧй картаӧ. / Чужӧй кӧзяйкалӧн / Старӧй кӧзяйкалӧн сёян-юаныс / твёрдӧй калень да льс / Выль кӧзяйкалӧн сёян-юаныс / свежӧй трава да мягкӧй хлеб.”

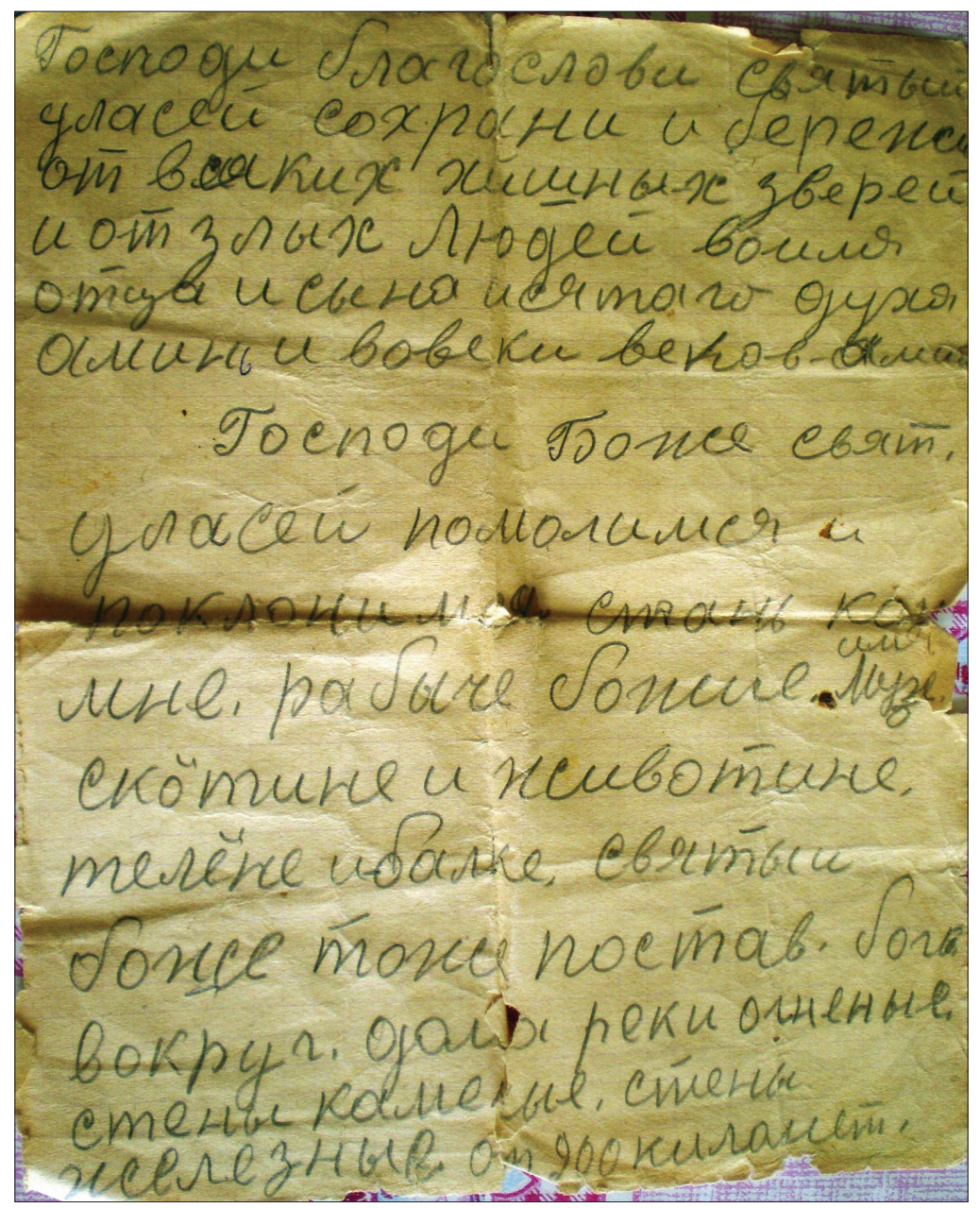

Figure 6. An incantatory text in the handwritten notebook of Nina Matveeva, born in 1931 (FFA: 28_06-142). Village of Yortom, Udorsky District. Photograph by Liudmila Lobanova 2011. 
According to the writings made between the lines and the comments of the informant provided by her during the interview, this incantation was used both when buying a cow and when letting it to the pasture.

The next text in the notes of the same informant (Fig. 6) refers to the cases when incantations are recorded in order to pass them on to someone else. It should be pointed out that, unlike other notes in the notebook of the informant, the text was written in different handwriting and on a separate piece of faded paper. While commenting on the notes, the informant mentioned that this incantation would be said whenever something happened to the cattle, ${ }^{41}$ and the text was recorded and passed on to her by an old woman from the village of Krestovo ${ }^{42}$ :

Господи Боже свят Уласей, пололился и поклонился! И стань ко мне, рабыче божие (иля) Музе скӧтине и животине, телёне и балке. Святы и боже тоже постав бога вокруг дола реки огненые, стены каленье, стень железные от 200 киланет. От зелли и до небес, вовеки веков. Алин.

My God My God Saint Ulasey, we pray and bow! Stand near me, the servant of God (name) the Muze, cattle and animals, calves and sheep. My Saint God, also do put the fiery river around the house, stone walls, iron walls from 200 kilometres (?). From the earth and to heaven, for ever and ever. Amen.

\section{Ritual dialogue}

The verbal level in certain rituals is represented by a dialogue between the two participants of the ritual, and it consists of two or three components. Ritual dialogues in the Slavic tradition have been studied by Nikita Tolstoi (1984, 1993). They have been classified and distributed into eleven topic groups. One of the groups combines ritual dialogues with the magical function of 'keeping fowl and cattle at home'. The main purpose of the rituals within this group is domesticating fowl and cattle before the start of the pasture period. In the majority of the Slavic traditions, such rituals were timed with Christmas rites, and in the northern Slavic tradition they coincided with Holy Thursday or were performed occasionally (Tolstoi 1984: 26-30; 1993: 85-87).

Such rituals were recorded in the southern districts of the Komi Republic. They were held on the morning of Holy Thursday ${ }^{43}$ with the purpose of domesticating the cattle. One of the participants went out into the yard or the hayloft and took a cow around the house (Konakov 1993: 56), and another one stayed 
at home, and they were talking with each other: Are the cows at home? - They are! They are! - Have the sheep come back? - They have! (Komi Calendar 2002: 67) It was believed that after that, the cows would always come back home from the pasture. Similar rituals were held in cowsheds at state-owned farms. On the morning of Holy Thursday, after coming to the cattle yard, milkmaids were talking with each other: Мӧсъяс ставыс абу? - Cтавыс-ставысc ${ }^{44}$ 'Have all of the cows come back? - Yes, all of them!', to make sure cows come back from the pasture and do not get lost.

Other recorded ritual dialogues are aimed at the treatment of diseases among people and cattle. Tolstoi, while studying this group, points out the 'incantatory' nature and distribution of these rituals among the Russians as well as the diversity of the means of exterminating illnesses, which are fumigated, burned, chopped, evaporated, etc. (Tolstoi 1984: 45-50; 1993: 92-98). Ritual dialogues said while fumigating a cow were recorded in the Komi tradition. In some cases, the ritual was held on the third day of the calving. "The mistress took a bowl, put a juniper spur into it, a couple of single hairs from her head, moss from three corners of the house, a chip from the threshold of the house, some hay from her shoes, and a piece of frankincense. Then she burned all of those components in the cowshed, and gave a whiff of the smoke to the cow and the calf, and then she walked around them three times. While she was doing that, she was talking to an imaginary interlocutor:

- Мыцй тшынан,

Мыци тшыннан?

- Волидзкыв тиынна.

Тьфбу волидз курваэс

Ёна колэ тшьнны.

(Vetoshkina 1982: 89-90)
- What are you purifying,

What are you purifying?

- I'm purifying the incantation.

Pooh-pooh, the incantation,

You should purify it more'.

The researcher determined the purpose of performing the ritual as 'protecting a domestic animal from blight with the help of the smoke' (ibid.).

In other adaptations, the smoke purification ritual was held with the purpose of throwing off an illness that had developed as a result of someone putting a curse on the animal. The range of objects used for purifying the animal included juniper collected on Holy Thursday and kept in the cowshed as a protective charm; pike teeth; chips from the threshold of the cowshed; cobwebs collected in the corners of the cowshed; the wool of the animal that was being purified or that was sheared from the tail base, forehead, or tail; and hay. The set of objects was set on fire, and one of the participants in the ritual asked 
questions, while the other one, who was walking around the cow against the sun, answered them:

- Кодэс тшынан?

- Кекуре ки волидзес, урекиволидзес. Кьтыссь волін, бӧр сэтче мун, пиняд бӧжтэ курччи да тодьєн лойси. ${ }^{45}$
- Who are you purifying?

- I'm purifying against the evil eye. Go back from where you arrived, bite your tail with your teeth and wallow in the bog.

The last two ritual dialogues have closing sentences, i.e. 'fasteners'. In the first case, the 'fastener' reinforces the action, while in the second case, it finishes the treatment ritual by sending the illness away.

\section{Lamentation}

In spite of the fact that I only have two examples of such texts at my disposal, ${ }^{46}$ I can have a look at their characteristics. The Komi lamentation tradition is regarded as being quite well-developed. There are local lamentation traditions and genre variations. For instance, in the Izhemsky Komi tradition, there are not only funeral and wedding lamentations, but also lullabies and calendar and labour lamentations (Filippova 2002).

\section{(Мӧсльь бӧрдэл)}

Тайтӧ, матиӧ, тайтӧ, Сюрка, Тайтӧ, тайтӧ, шӧӧ мада

Пукси шӧо̆, шооо

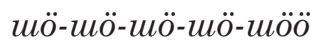

Гортӧ мидаэ, гортӧ,

Гортӧ, гортӧ, матиӧ

Гортӧ, гортӧ, чӧскьљ йӧлаэ

Гортэ, гортэ, лидаэ.

Гортэ локтэ, баксэ, тӧдэ кӧзяйка, и локтэ шылас мӧскьс. Мадаэ бара шыıас воис и бакестас, $и$ кукйыс поллась.
(Lamentation for a cow)

Come, mother, come, Syurka (literally 'Horned'), Come, come, shöö darling, Puksi shöö, shöö, shö-shö-shö-shö-shöö, Come home, darling, home, Home, home, mother, Home, home, with delicious milk, Home, home, darling,

She's coming home, mooing, she knows her lady and knows her voice. She will come by her lady's voice and moo, and her calf will moo back. 
Мӧс дзоньтэл:

Тайтэ, мадаэ,

Тайтэ, Сюрка

тайтэ, мадаэ,

Тайтэ, тайтээ,

Сӧӧ, миадаэ,

Cö-cö-cö-cö

Чӧскыд йӧлале сӧ.

Гортэ мадаэ,

Гортэ, гортэ $!^{47}$
Caressing the cow:

Come, cow, come, darling,

Come, cow, Syurka,

Come, cow, come, darling,

Come, cow, come.

Söö, darling

Sö-sö-sö-sö

With delicious milk sö,

Home, darling,

Home, home!

The recorded lamentations are proximal to lullabies. It is interesting to point out that in the first case, the text is called лӧсль боррдэл 'lamentation for a cow', while in the second case it is referred to as мӧс дзоньтэл, using a verbal noun derived from the verb дзоньтьньь 'to fix, make it whole again', which also means 'to caress' in the Izhemsky dialect of the Komi language. The function of the text can be regarded as caressing the animal to keep it healthy.

\section{CONCLUSION}

On the basis of the material collected about the Komi cattle-breeding tradition, represented mainly in the form of modern notes, different forms of incantatory texts can be distinguished. Proceeding from their formal characteristics, I have divided them into five categories. But we should not forget that these texts represent the verbal level of a ritual, and in order to carry out a thorough analysis, the semantics and structure of the ritual itself should also be studied, and the interrelations between the actional and object-specific codes of rituals must be identified. In addition to that, the comments of informants, the socalled 'speech context', and the poetics of the texts, which should be analysed in order to study the verbal level of cattle-breeding rituals, were left without consideration.

\section{ABBREVIATIONS}

AAC - Author's audio collection

FA of SSU - Folklore Archive of Syktyvkar State University

FF of ILLH - Folklore Archive of the Institute of Language, Literature, and History 
NMKR - National Museum of the Komi Republic

AHC - Author's handwritten collection

SA Komi SC - Scientific Archive of the Komi Scientific Centre of the Ural Branch of the Russian Academy of Sciences

\section{NOTES}

1 Protective house spirit.

2 It is comparable with the notion of ас гӧгӧр тӧднь 'knowledge about (literally 'around') yourself', челядь гӧгӧр тӧдньь 'knowledge about (literally 'around') children', and it means the preservation of integrity and health on the whole, and is based on the preventive aspect of the incantatory Komi tradition (Panyukov 2009: 166-204).

3 Recorded by L. Lobanova in the village of Anyb, Ust-Kulomsky District, in 1994, from Valentina Lobanova, born in 1953 (AAC).

4 Нимкьљв means an incantation, an incantatory act (Ulyashev 1999; Panyukov 2009: 166-204).

5 Recorded by L. Lobanova in the village of Cheksha, Noshulsky village soviet, Priluzsky District, on 23 June 2006, from Aleksandr Vakhnin, born in 1928 (AAC).

6 See Neklyudov 2011 about the differences of ritual practice and information about it.

7 Material collected by Pavel Savvaitov, dating back to the middle of the nineteenth century, is archived in the Manuscript Department of the Russian National Library (St. Petersburg); material collected by Vasily P. Nalimov at the beginning of the twentieth century is preserved in the Archive of the Finno-Ugric Society (SuomalaisUgrilaisen Seuran Arkisto); the folkloric-ethnographic material collected by the students of the Pedagogical College in the 1930s is preserved at the National Museum of the Komi Republic; the material of folkloric-ethnographic and linguistic fieldwork collected by the staff of the Komi Scientific Centre in the 1960-1980s.

8 Recorded by G. Savelyeva \& A. Panyukov in the village of Puchkoma, Udorsky District, in 1999, from Maria Matveeva, born in 1946 (FF of ILLH: A0525-13).

9 Recorded by L. Lobanova in the village of Gar, Spasporubsky village soviet, Priluzsky District, on 20 June 2005, from Klavdia Fomina, born in the village of Kuliga in 1937 (FF of ILLH: A 1564).

${ }^{10}$ Recorded by L. Lobanova in the village of Yortom, Udorsky District, on 23 June 2001, from Galina Matveeva, born in 1961 (AAC).

${ }^{11}$ Recorded by G. Savelyeva \& A. Panyukov in the village of Nivshera, Kortkerossky District, in 2000, from Anna Slyuser, born in 1906 (FF of ILLH: B1114-73).

${ }^{12}$ Recorded by T. Kaneva in the village of Ozyag, Kuzhbinsky village soviet, UstKulomsky District, in 1999, from A. Yeseva, born in 1927 (FF of ILLH: B1206). 
${ }^{13}$ Recorded by G. Savelyeva \& A. Panyukov in the village of Puchkoma, Udorsky District, in 1999, from Maria Matveeva, born in 1946 (FF of ILLH: B0510-69).

${ }^{14}$ Recorded by L. Lobanova on 23 in the village of Yortom, Udorsky District, on 23 June 2011, from Nina Matveeva, born in 1931 (AAC).

15 They mean the prayer 'Let God rise'.

${ }^{16}$ Recorded by G. Savelyeva \& A. Panyukov in the village of Nivshera, Kortkerossky District, in 2000, from Aleksandra Zhizheva, born in 1928 (FF of ILLH: B1113-44).

17 The specified meaning of the particle maŭ, which occurs in the Izhemsky dialect, is specified in the work of Galina Fedyuniova with the indication of the possible etymology of this particle (Fedyuniova 2009: 72).

${ }^{18}$ Recorded by E. Vetoshkina in the village of Lyaty, Kozhmudorsky village council, Ust-Vymsky District, in 1978, from Olga Kozlova, born in 1918 (SA Komi SC: F.5. Op. 2. L.226-v. L.48).

19 The definitions of closed structure and open structure were formulated by V. Kharitonova (1992).

${ }^{20}$ In the Komi language there is one word for wool and down feather.

${ }^{21}$ Recorded by G. Savelyeva \& A. Panyukov in the village of Puchkoma, Udorsky District, in 1999, from Maria Matveeva, born in 1946 (FF of ILLH: A0525-14).

${ }^{22}$ Recorded by L. Lobanova in the village of Yortom, Udorsky District, on 23 June 2001, from Galina Matveeva, born in 1961 (AAC).

${ }^{23}$ Recorded by L. Lobanova in the village of Yortom, Udorsky District, on 23 June 2011, from Nina Matveeva, born in 1931 (AAC).

${ }^{24}$ Recorded by G. Savelyeva \& A. Panyukov in the village of Nivshera, Kortkerossky District, in 2000, from Aleksandra Zhizheva, born in 1928 (FF of ILLH: B1113-46).

${ }^{25}$ Recorded by G. Savelyeva \& A. Panyukov in the village of Nivshera, Kortkerossky District, in 2000, from Aleksandra Zhizheva, born in 1928 (FF of ILLH: B1113-47).

${ }^{26}$ Recorded by L. Kondratyeva in the village of Uzhga, Koygorodsky District, in 1935, (NMKR: KP-12485. L. 514).

${ }^{27}$ Recorded by Tarakanova in the village of Pazhga, Syktyvdinsky District, in 1935 (NMKR: KP-12485. L. 497).

${ }^{28}$ Recorded by K. Rédei at the Upper Vychegda in 1964 (Rédei 1978: 234).

${ }^{29}$ Recorded by G. Savelyeva \& A. Panyukov in the village of Nivshera, Kortkerossky District, in 1996, from Maria Mikhailova, born in 1922; and from Agnia Zhizheva, born in 1937 (FF of ILLH: B1102-41).

${ }^{30}$ Recorded by G. Savelyeva \& A. Panyukov in the village of Nivshera, Kortkerossky District, in 1996, from Nina Mikhailova, born in 1923 (FF of ILLH: B1102-19). 
${ }^{31}$ Yoma is a Komi folkloric and mythological character. In this case Yoma acts as a marker of a foreign space as opposed to the sheep's own household.

${ }^{32}$ Recorded by L. Lobanova in the village of Kuliga, Spasporubsky village soviet, Priluzsky District, on 22 June 2005, from Maria Fomina, born in the village of Shpal in 1928 (AAC).

${ }^{33}$ Recorded by L. Lobanova in the village of Gar, Spasporubsky village soviet, Priluzsky District, on 20 June 2005, from Klavdia Fomina, born in the village of Kuliga in 1937 (FF of ILLH: A1564).

${ }^{34}$ Recorded by L. Lobanova in the village of Anyb, Ust-Kulomsky District, in 1994, from Valentina Lobanova, born in 1953 (AAC).

${ }^{35}$ Recorded by L. Lobanova in the village of Yortom, Udorsky District, on 28 June 2011, from Nina Matveeva, born in 1931 (AAC).

${ }^{36}$ Recorded by L. Lobanova in the village of Anyb, Ust-Kulomsky District, in 1994, from Anna Pimenova, born in 1914 (AAC).

${ }^{37}$ Recorded by V. Arefyeva in the village of Chuprovo, Udorsky District, in 2011, from N. M. Shlopova, born in 1946 (AHC).

${ }^{38}$ Recorded by V. Arefyeva in the village of Muftyuga, Chuprovsky village council, Udorsky District, in 2011, from Nina Fedorova, born in 1955 (AHC).

${ }^{39}$ Added in different handwriting in black ink.

${ }^{40}$ Added above the next line in different handwriting in blue ink.

${ }^{41}$ Recorded by L. Lobanova in the village of Yortom, Udorsky District, on 28 June 2011, from Nina Matveeva, born in 1931 (AAC).

42 The village of Krestovo was a part of the Yortomsky village soviet. This place is remarkable in that it held the status of a religious centre. A monastery stood here once, on the territory of which the first church in Yortom village was founded.

${ }^{43}$ The rituals that were held on Holy Thursday are described in detail in Lobanova 2012.

${ }^{44}$ Recorded by A. Rassykhaev and L. Sazhina in the village of Karvudzhem, Grivensky village soviet, Koygorodsky District, in 2002, from E. M. Ushakova, born in 1918 (FF of ILLH: A1604).

${ }^{45}$ Recorded by L. Lobanova in the village of Anyb, Ust-Kulomsky District, in 1994, from Anna Pimenova, born in 1914 (AAC).

${ }^{46}$ I am grateful to the staff of the Folklore Archive of the Institute of Language, Literature and History, Galina Savelyeva and Anatoly Panyukov, for providing me with these texts and for the opportunity to study them.

${ }^{47}$ Recorded by A. Mikushev and P. Chistalyov in the village of Brykalansk (Kotlas), Izhemsky District, in 1960, from Ulyana Smetanina, 65 years old, and from Anna Smetanina (FF of ILLH: K-45: 12). 


\section{REFERENCES}

Fedosova, Kseniia 2007. Zagovory v obriade pervogo vygona skota: printsipy var'irovaniia $i$ strategii tekstoporozhdeniia v ustnoi i pis'mennoi traditsii. [Incantations in the Ceremony of the First Grazing of the Cattle: The Principles of Variation and Strategy of Text Creating in Oral and Written Tradition.] Avtoreferat dissertatsii na soiskanie uchenoi stepeni kandidata filologicheskikh nauk. Moscow University. Available at http://www.dslib.net/folklor/zagovory-v-obrjade-pervogo-vygonaskota-principy-varirovanija-i-strategii.html, last accessed on 15 May 2019.

Fedyuniova 2009 = Fediuneva, Galina. K etimologii chastitsy tai 'ved', zhe' v komi i mansiiskom iazykakh. [To the Etymology of the Particle tai 'After All' in the Komi and Mansi Languages.] Gumanitarnye nauki v Sibiri, No. 4, pp. 70-72.

Filippova, Valentina 2002. Prichitanie v kontekste obriadovoi poezii. [Lamentation in the Context of Ceremonial Poetry.] In: P. Limerov (ed.) Fol'kloristika Komi. Syktyvkar: Izdatel'stvo Komi NTs UrO RAN, pp. 61-72.

Kharitonova, Valentina 1992. Zagovorno-zaklinatel'naia poeziia vostochnykh slavian: Konspekty lektsii. [Incantatory Poetry of the East Slavs: Synopses of Lectures.] Lviv: LGU.

Komi Calendar 2002 = Filippova, Valentina \& Kaneva, Tat'iana (comps.), Vlasov, Andrei (ed.) Traditsionnyi narodnyi kalendar' komi: Materialy. [Komi Traditional Folk Calendar: Materials.] Syktyvkar: SGU.

Konakov, Nikolai 1993. Ot Sviatok do Sochel'nika: Komi traditsionnye kalendarnye obriady. [From Christmastide to Christmas Eve: Komi Traditional Calendar Rituals.] Syktyvkar: Komi knizhnoe izdatel'stvo.

Kudryashova 1991 = Kudriashova, Vera. Zagovory naroda komi. [Incantations of the Komi People.] In: Iurii Rochev (ed.) Obshchee i osobennoe v zhanrakh komi fol'klora i literatury. Trudy Instituta iazyka, literatury i istorii, Vyp. 48. Syktyvkar: Komi nauchnyi tsentr UrO AN SSSR, pp. 34-45. Available at https://www.booksite.ru/ fulltext/komifolk/text.pdf, last accessed on 15 May 2019.

Lobanova, Liudmila 2012. Skotovodcheskie ritualy Velikogo chetverga. [Cattle Breeding Rituals on Maundy Thursday.] Fol'kloristika komi. Trudy instituta iazyka, literatury i istorii, Vyp. 70. Syktyvkar: Komi NTs UrO RAN, pp. 101-121.

Lytkin \& Gulyaev 1999 [1970] = Lytkin, Vasilii \& Guliaev, Evgenii. Kratkii etimologicheskii slovar' komi iazyka. [Concise Etymological Dictionary of the Komi Language.] Syktyvkar: Komi knizhnoe izdatel'stvo.

Neklyudov 2011 = Nekliudov, Sergei. "Etnograficheskii fakt" i ego fol'klornye eksplikatsii. ["The Ethnographic Fact" and Its Folkloric Explications.] In: A. Baiburin \& T. Shchepanskaia (eds.) Fol'klor $i$ etnografiia. $K$ devianostoletiiu so dnia rozhdeniia K. V. Chistova. St. Petersburg: MAE RAN, pp. 40-47. Available at http://www.kunstkamera.ru/files/lib/978-5-88431-209-8/978-5-88431-209-8.pdf, last accessed on 15 May 2019.

Panyukov 2009 = Paniukov, Anatolii. Dinamika razvitiia komi fol'klornykh traditsii $v$ kontekste teorii samoorganizatsii. [Development Dynamics of Komi Folk Traditions in the Context of the Theory of Self-Organization.] Syktyvkar: Izdatel'stvo Komi NTs UrO RAN. 
Permyakov 1988 = Permiakov, Grigorii. K voprosu o strukture paremiologicheskogo fonda. [On the Question of the Structure of the Paroemic Corpus.] In: G. Permiakov. Osnovy strukturnoi paremiologii. Moscow: Nauka, pp. 80-106. Available at https://www.ruthenia.ru/folklore/permyakov1.pdf, last accessed on 15 May 2019.

Popova, Eleonora 2000. Mezhdometie. [Interjection.] In: Galina Fediuneva (ed.) Öniia komi kyv. Sovremennyi komi iazyk: Morfologiia. Syktyvkar: Komi knizhnoe izdatel'stvo.

Rédei, Károly 1978. Zyrian Folklore Texts. Budapest: Akadémiai Kiadó.

Sidorov, Aleksei 1997 [1928]. Znakharstvo, koldovstvo i porcha u naroda komi: Materialy po psikhologii koldovstva. [Folk Healing, Magic and Witchcraft among the Komi People: Materials of the Psychology of Magic.] St. Petersburg: Aleteiia. Available at https://www.booksite.ru/fulltext/sidorov/text.pdf, last accessed on 15 May 2019.

SSKZD 1961 = Zhilina, Tat'iana \& Sakharova, Marfa \& Sorvacheva, Valentina (comps.) Sravnitel'nyi slovar' komi-zyrianskikh dialektov. [Comparative Dictionary of the Komi-Zyrian Dialects.] Syktyvkar: Komi knizhnoe izdatel'stvo.

Tolstoi, Nikita 1984. Fragment slavianskogo iazychestva: arkhaicheskii ritual-dialog. [A Fragment of the Slavic Paganism: Archaic Ritual Dialogue.] In: N. Tolstoi (ed.) Slavianskii i balkanskii fol'klor: Etnogeneticheskaia obshchnost' i tipologicheskie paralleli. Moscow: Nauka, pp. 5-72. Available at https://inslav.ru/images/stories/ pdf/SBF-1984.pdf, last accessed on 15 May 2019.

Tolstoi, Nikita 1993. Eshche raz o slavianskom ritual'nom dialoge. [Once Again about the Slavic Ritual Dialogue.] In: S. Tolstaia \& T. Tsiv'ian (eds.) Slavianskoe $i$ balkanskoe iazykoznanie: Struktura malykh fol'klornykh tekstov. Moscow: Nauka, pp. 82-110. Available at https://inslav.ru/images/stories/pdf/SBJa-1993. pdf, last accessed on 15 May 2019.

Ulyashev 1999 = Uliashev, Oleg. Nimkyv. [Incantation.] In: Anna-Leena Siikala \& Vladimir Napol'skikh \& Mihaly Hoppal (eds.) Entsiklopediia ural'skikh mifologii. T. 1. Mifologiia komi. Moscow \& Syktyvkar: DIK, pp. 256-258. Available at https://www.academia.edu/8463469/, last accessed on 16 May 2019.

Uotila, Toivo 2006. Syrjänische Texte. Band V. Komi-Syrjänisch: Ober-Vyčegda-Dialekt. M. Žikins Texte. Gesammelt von T. E. Uotila, übersetzt und herausgegeben von P. Kokkonen. Helsinki: Suomalais-Ugrilaisen Seura.

Vetoshkina, Elena 1982. Proizvodstvennye i semeino-bytovye zagovory u komi. [Production and Family-Household Incantations among the Komi People.] Natsional'noe i internatsional'noe v komi literature i fol'klore. Trudy Instituta iazyka, literatury i istorii, Vyp. 26. Syktyvkar: Komi NTs UrO RAN, pp. 87-97.

Zhilina, Tatiana 1975. Verkhnesysol'skii dialekt komi iazyka. [Upper-Vychegda Dialect of the Komi Language.] Moscow: Nauka. 